\title{
Zero Tilled Dibbled Sunflower Enables Planting Earlier and Harvests More in the Coastal Saline Area of Bangladesh
}

\author{
M. Harunur Rashid, Shama Nasrin, and Debabrata Mahalder
}

\begin{abstract}
Only transplanted Aman (T. Aman) rice is one of the major cropping sequences in the medium saline, irrigation water lacking area of the coastal Bangladesh which requires suitable succeeding crop with early planting in moist soil and to escape damage from the effect of storm surges and water logging due to rainfall in May. A field trial was conducted in 2012 to compare the early dibbled sunflowers in zero tilled soil with traditional tilled one after T. Aman rice. Sunflower was planted on four dates, 14 January (zero tillage in moist soil), 22 and 29 February and 5 March (tilled field at field capacity). Results indicated that dibbling on 14 January produced significantly taller plant, larger head and higher seed yield (3.06 $\left.\mathrm{t} \mathrm{ha}^{-1}\right)$ than those of other planting dates $\left(2.54\right.$ to $\left.2.68 \mathrm{t} \mathrm{ha}^{-1}\right)$. The farmers' led validation of zero tilled dibbled sunflowers in the following year confirmed its earlier planting and higher productivity.
\end{abstract}

Index Terms-Agro-economic productivity, dates of sowing, saline soils, sunflower.

\section{INTRODUCTION}

Out of 2.85 million hectares of the coastal and offshore areas of Bangladesh about 0.83 million hectares are arable lands. This arable land is more than $30 \%$ of the total cultivable lands. Agricultural land use in the coastal districts is very poor. The average cropping intensity of the country was $179 \%$ in $2007-08$, whereas it was $128-147 \%$ in southern districts [1]. The major part of this land is affected by different gradient of salinity. The low land use in saline area is mainly due to unfavorable soil salinity in dry season and unavailability of quality irrigation water [2]. Salinity causes unfavorable environment and hydrological situation that restrict normal crop production throughout the year. Salinity in the country received very little attention in the past. The increased pressure of growing population demand more food that brings attention to explore the possibilities of increasing the potential of the saline lands for increased production of crops.

The flood and tidal water recedes from October to late December in the coastal area. Depending on topographical position and drainage facilities, water recede from about $24 \%$ area within October, from about 53\% area in November and

Manuscript received July 3, 2013; revised October 24, 2013. This work was supported in part by the USAID funded Cereal System Initiative for South Asia (CSISA-BD) project.

M. Harunur Rashid, Shama Nasrin, and Debabrata Mahalder are with the International Rice Research Institute, House No. 9, Road 2/2, Banani, Dhaka-1213, Bangladesh (e-mail: m.h.rashid@irri.org, s.nasrin@irri.org, d.mahalder@irri.org ).
mid-December and from about 23\% area in late December [3]. Most of the coastal areas are dominated by medium highlands, where flooding depth ranges from 0.3-0.9 meter. This category of land is suitable for minimum two crops and sometimes three crops. But only medium to long duration transplanted Aman (T. Aman) rice (wet season rice) is the predominant cropping sequence in the region. The slow drying process after harvest of $\mathrm{T}$. Aman rice delayed to reach the soil in field condition or suitable for ploughing the land for dry season winter (rabi) and pre-mosoon crops. Generally the situation leads to seeding of rabi crops during the first fortnight of February which is often affected by soil salinity. The cultivation of dry season crop in this worse situation requires suitable crops and agronomic options suitable for early planting in the excess moist soil, more than field capacity which is unable to plough to increase the productivity and cropping intensity. The cultivation of sunflower may be suitable in this environment because of its high yield as well as its extensive adaptability and acclimation, high photosynthesis potential and high harvest index [4]. Sunflower dibbled in the moist soil under zero tillage may be suited in coastal saline environment.

Sunflower (Helianthus annuus L.) is the world's fourth largest oil-seed crop [5]. It is grown as a source of vegetable oil and protein. It can be focused as the suitable crop as edible oil source in Bangladesh. It is short duration, relatively drought tolerant and has shown potential to reduce the existing gap between production and consumption of edible oil because it contains $40-50$ percent oil, and rich in protein 23 percent [6]. The present domestic edible oilseed production is 373 thousand tons which meets only one third of national demand [7]. The present per capita oil consumption is only $10 \mathrm{~g}$ day $^{-1}$ as compared to the total need of $22 \mathrm{~g} \mathrm{day}^{-1}$ [8].

Sunflower is categorized as a low to medium drought sensitive crop [9]-[11]. It is widely adaptable and more drought tolerant than most other grain crops. It is a very efficient user of soil moisture as a result of its deep and branched tap root system penetrating to deeper zone, aids the plant during water stress. Even in the sub-soil and on heavy clay soils it utilizes moisture reserves far more effectively. According to a classification based on water stress day index, sunflower was determined as a moderately sensitive crop to salinity [12].

Sunflower can successfully be grown over a wide range of geographic area and is considered a crop adapted to a wide range of environment. However, yield is reduced when normal sowing is delayed in temperate and subtropical 
environments. The lower yields associated with late plantings have been hypothesized as due to warmer temperatures during the early growth period, which promotes excessive early stem growth and reduces time to flowering, while in cooler temperatures, reduced incident radiation post anthesis affects dynamics of grain filling [13]. Numerous studies have shown that yield and yield components of sunflower are reduced when normal sowing dates are delayed [14]. In view of the importance of planting date, the present investigation was designed to study the effects of planting dates on yield and yield components of sunflower and to compare the zero tilled earlier dibbled sunflowers in moist soil with the traditional dibbled done under tilled condition at field capacity for increased productivity in coastal saline environment of Bangladesh.

\section{MATERIALS AND MeTHODS}

\section{A. Experimental Site and Seasons}

The field trial was conducted with four dates of sowing following unploughed and ploughed dibbling during dry season in 2012 at Katianangla village in Batiaghata Upazila of Khulna District $\left(22^{\circ} 40^{\prime} \mathrm{N}\right.$ and $\left.89^{\circ} 31^{\prime} \mathrm{E}\right)$ in Bangladesh. Early sown zero tilled dibbled method was identified as a better option from the trial. Farmers' led validation was conducted in trial and adjacent villages in 2013. The area belongs to the agro-ecological zone of the Ganges Tidal Floodplain. The climate of the area is subtropical. The soils of the experimental fields at $0-15-\mathrm{cm}$ depth were clay loam in texture, with a $\mathrm{pH}$ of 8.10 , organic $\mathrm{C}$ of $6.44 \mathrm{~g} \mathrm{~kg}^{-1}$, total $N$ of $1.0 \mathrm{~g} \mathrm{~kg}^{-1}$, available $P$ of $4.55 \mathrm{mg} \mathrm{kg}^{-1}$, exchangeable $K$ of $0.40 \mathrm{meq} 100 \mathrm{~g}^{-1}$, available $\mathrm{S}$ of $75.7814 \mathrm{mg} \mathrm{kg}^{-1}$, and $\mathrm{Zn}$ of $1.27 \mathrm{mg} \mathrm{kg}^{-1}$.

\section{B. Experimental Design and Treatments}

The field experiment was arranged in a randomized complete bock design with four replications in 2012. The experimental field had a similar crop management history and uniform soil type. The planting dates were randomly assigned to the replications. The dibbling dates were (a) zero tilled dibbled in moist soil on 14 January, (b) dibbled in tilled soil at field capacity on 22 February, (c) dibbled in tilled soil at field capacity on 29 February, (d) dibbled in tilled soil at field capacity on 05 March. The first date was selected observing the moisture of the soil where dibbling was comfortable by hand and easy to germinate the soil. The other dates were selected based on the soil moisture suitable for tilling (field capacity) which varied due to the elevation of the experimental fields. In 2013, participatory farmers were trained on zero tilled dibbled sunflower cultivation who adopted the package of technology after harvest of T. Aman rice.

\section{Crop Establishment}

Sunflower was grown in the dry season of 2012 (January to May). After harvesting of $T$. Aman rice, seeds of sunflower were dibbled by hand in zero tilled condition where the soil moisture was 42 to $45 \%$ which was unable to plough for the first date of sowing. The rest of plantings were done in tilled soil at field capacity having 29 to $35 \%$ moisture. The experimental plots were prepared with three passes by a power tiller followed by two ladderings prior to dibbling in case of all dates of sowing except the first one. The hybrid cultivar, Hysun33 was used as a test crop. Two seeds per hill were dibbled manually maintaining $75 \mathrm{~cm}$ row and $45 \mathrm{~cm}$ plant spacing. Plants were thinned to one plant per hill at 15 days after planting. The crops were harvested in $3^{\text {rd }}$ week of April in case of first planting and third to fourth week of May for other dates of planting. In fertilizer management practices, the fertilizer rates $\left(\mathrm{kg} \mathrm{ha}^{-1}\right)$ were $115 \mathrm{~N}, 40 P, 70 \mathrm{~K}, 29 \mathrm{~S}, 5 \mathrm{Zn}$ and $1.4 \mathrm{~B}$. The total amounts of $P$ as triple superphosphate, $\mathrm{K}$ as $\mathrm{KCl}, S$ as gypsum, $\mathrm{Zn}$ as zinc sulfate and $\mathrm{B}$ as Boric Acid and a half of $\mathrm{N}$ as urea were applied basally at final land preparation under all the planting except the first planting. In case of first planting under zero tillage, those fertilizers were applied opening a furrow near the seed at 15 days after seeding (DAS). The remaining of the nitrogen was applied at 25 days after dibbling and before flowering in equal splits. The plots under first date of seeding were irrigated once whereas others were not irrigated due to occurrence of rainfall at the stage for fertilizing the crops. The dates of dibbling under farmers' led validation during second year were monitored and was grouped as weekly basis and presented.

\section{Measurement}

Surface soil $(0-15 \mathrm{~cm})$ samples collected from the trial plots were air-dried and sieved with $2 \mathrm{~mm}$ sieve and analyzed for the initial soil properties and electrical conductivity in different dates. Ten randomly tagged plants from each plot were evaluated for plant height, head diameter, seed per head, sterility percent, 1000 - seed weight. Head diameter was measured with the help of vernier caliper. The heads were threshed manually and number of seeds per head was counted. Three lots of 1000 seeds were weighed for thousand seed weight with the help of electronic weight balance and average was calculated. Seed yield and biological yield were obtained from an area of $6.75 \mathrm{~m}^{2}$ of the central part of each plot. The seed yield was measured and adjusted at $9 \%$ moisture and expressed as $\mathrm{tha}^{-1}$. The collected sample from each plot was dried to constant weight and biological yield was determined. The harvest index was computed by dividing the seed yield by the biological yield and was expressed as percentage.

\section{E. Analyses}

The statistical analysis of the data was done using Crop Stat Version 7.2. Unless indicated otherwise, differences were considered significant only at $P \leq 0.05$. Economic analysis was performed to determine the efficiency of different planting dates. The amount of different input required per hectare was calculated and the cost of input for different planting dates was estimated based on their local market price. Labor wage for different operations of crop cultivation was captured and included in the total variable cost (TVC). The farm gate price of sunflower seed and stalk was used for calculating gross return (GR). In case of farmers' validation, the economic return was calculated based on seed yield only. The gross margin (GM) per hectare for each treatment option was calculated by deducting the 
total variable cost from the gross return. The benefit cost ratio (BCR) was calculated dividing the gross return by TVC.

\section{RESULTS AND DISCUSSIONS}

\section{A. Growth and Yield Components}

Differences in growth and yield components of sunflower among sowing dates were significant except the sterility percent and 1000 seed weight (Table I). Dibbled on 14 January produced the tallest plant $(1.59 \mathrm{~m})$ which was significantly higher than plants of all other planting dates. The later planting dates produced the plants of similar height which were reduced by 8 to $10 \%$ compared to first planting. The head diameter showed a decreasing trend with delayed sowing. The first planting (14 January) had the largest head diameter $(16.14 \mathrm{~cm})$ while the crop planted on last sowing (March 05) produced the heads of smallest size $(12.75 \mathrm{~cm})$. The sowing of sunflower on 22 and 29 January produced the head of similar size which were significantly larger than the last sowing. The reasons of smaller head might be related to the overall plant structure. Number of seeds per head decreased when sowing was delayed up to 5 March (888). The sunflower dibbled on 14 January, 22 and 29 February produced 1108, 1072 and 1063 seeds per head, respectively, which were at par among each other but significantly higher than 5 March planting. The lesser number of seeds found in delayed sowing might be related to the head size. Earlier sowings produced larger heads those ultimately encouraged the higher number of seed setting. Failures in seed set with delayed sowing because of either of fertilization or embryo abortion in the central portion of the floral disc [15]. The sterility percent and 1000 seed weight were not affected by dates of planting. The sterility ranged 13.28 to $13.63 \%$ while 1000-seed weight ranged 64.50 to $65.37 \mathrm{~g}$, respectively. Changes in environmental conditions during the seed filling period potentially effects sunflower yield components [16]. Many researchers reported that seed yield in sunflower largely dependent on thousand seed weight, head diameter and seed yield plant ${ }^{-1}[17]-[21]$.

TABLE I: GROWTH AND YIELD COMPONENT OF SUNFLOWER AS AFFECTED BY SOWING DATES

\begin{tabular}{|c|c|c|c|c|c|}
\hline Sowing date & $\begin{array}{c}\text { Plant } \\
\text { height } \\
(\mathrm{m})\end{array}$ & $\begin{array}{c}\text { Head } \\
\text { diameter } \\
(\mathrm{cm})\end{array}$ & $\begin{array}{c}\text { Seed } \\
\text { head }^{-1} \\
\left(\mathrm{No}^{\prime}\right)\end{array}$ & $\begin{array}{c}\text { Sterility } \\
(\%)\end{array}$ & $\begin{array}{c}\text { 1000-seed } \\
\text { weight }(\mathrm{g})\end{array}$ \\
\hline 14 January & 1.59 & 16.14 & 1108 & 13.41 & 65.37 \\
\hline 22 February & 1.47 & 14.53 & 1072 & 13.63 & 65.30 \\
\hline 29 February & 1.46 & 14.18 & 1063 & 13.49 & 65.03 \\
\hline 5 March & 1.43 & 12.75 & 888 & 13.28 & 64.50 \\
\hline LSD $_{0.05}$ & 0.05 & 1.17 & 93 & $4.11(\mathrm{~ns})$ & $0.87(\mathrm{~ns})$ \\
\hline CV $(\%)$ & 1.7 & 4.1 & 4.5 & 15.3 & 0.70 \\
\hline
\end{tabular}

ns = not significant

\section{B. Growth Duration}

The number of days to maturity was reduced as the planting date was delayed (Table II). Planting on 14 January resulted in 98 days to maturity while the number of days to maturity in the 5 March planting was 89 days. An increased number of days to maturity induced by early sowing could be explained by the fact that delayed planting reduces the period required from sowing to flowering. On average, late-sown sunflower ( 5 March) reached maturity 12 days earlier than the early-sown sunflower (14 January). This result indicated that the number of days to maturity varied with temperature conditions during the growing season and planting date [22].

TABLE II: GROWTH DURATION AND DATES OF MATURITY AS AFFECTED BY SOWING DATES

\begin{tabular}{|c|c|c|c|}
\hline Sowing date & $\begin{array}{c}\text { Days to } \\
\text { maturity }\end{array}$ & Flowering date & Maturity date \\
\hline 14 January & 98 & 22 March & 16 April \\
\hline 22 February & 95 & 23 April & 22 May \\
\hline 29 February & 94 & 25 April & 27 May \\
\hline 5 March & 89 & 30 April & 27 May \\
\hline LSD $_{0.05}$ & 2.0 & - & - \\
\hline CV $(\%)$ & 1.1 & - & - \\
\hline
\end{tabular}

From the results it is found that zero tilled early dibbled sunflower on 14 January sowing matured more than one month earlier (Table II) had the opportunity to escape the damage the crop from the strong wind, tidal storm and water logging due to heavy rain which is very common in coastal area in the month of May.

The seed yield, biological yield and harvest indices were measured at maturity. The parameters as affected by sowing dates have been presented in Table III and Table IV.

\section{Seed Yield}

Seed yield was affected by date of sowing. The highest seed yield was produced from 14 January planting (3.06 t $\left.\mathrm{ha}^{-1}\right)$ significantly followed by 22 February planting $(2.68 \mathrm{t}$ $\left.\mathrm{ha}^{-1}\right)$ and 29 February planting $\left(2.59 \mathrm{t} \mathrm{ha}^{-1}\right)$. The lowest seed yield $\left(2.54 \mathrm{t} \mathrm{ha}^{-1}\right)$ was recorded in 5 March planting which was at par with 29 February planting. The higher seed yield might be attributed to the larger head and more number of seeds per head. The longer growth duration had the opportunity to contribute to those parameters in early planting both in trial and extrapolation area. The findings are the confirmatory with those of other findings [23]-[25]. In extrapolation area, the seed yield was further increased in January first week $\left(3.65 \mathrm{t} \mathrm{ha}^{-1}\right)$ and fourth week of December planting (3.31 t ha $\mathrm{h}^{-1}$ ). The difference between the sowing duration was significant and both were significantly higher than January second and $3^{\text {rd }}$ week planting. By planting sunflower earlier, plants are able to get the full benefit of soil moisture and nutrients during the extended growing season, allowing more total seeds head ${ }^{-1}$ to form and the achenes to mature because of sufficient time to fill.

TABLE III: SEED, BIOLOGICAL YIELD AND HARVEST INDEX AS AFFECTED BY SOWING DATES

\begin{tabular}{|c|c|c|c|}
\hline Sowing date & $\begin{array}{c}\text { Seed yield } \\
\left(\mathrm{t} \mathrm{ha}^{-1}\right)\end{array}$ & $\begin{array}{c}\text { Biological yield } \\
\left(\mathrm{t} \mathrm{ha}^{-1}\right)\end{array}$ & $\begin{array}{c}\text { Harvest index } \\
(\%)\end{array}$ \\
\hline 14 January & 3.06 & 7.90 & 0.49 \\
\hline 22 February & 2.68 & 7.23 & 0.43 \\
\hline 29 February & 2.59 & 6.71 & 0.44 \\
\hline 5 March & 2.54 & 5.76 & 0.49 \\
\hline LSD 0.05 & 0.07 & 0.92 & 0.05 \\
\hline CV $(\%)$ & 1.3 & 6.7 & 5.7 \\
\hline
\end{tabular}




\section{Biological Yield}

Biological yield represents the total amount of above ground biomass accumulation. The dates of sowing significantly affected the biological yield. The first sowing date produced the highest biological yield $\left(7.90 \mathrm{t} \mathrm{ha}^{-1}\right)$ followed by second planting but significantly higher than later two plantings. The biological yield of second planting $\left(7.23 \mathrm{t} \mathrm{ha}^{-1}\right)$ was at par with both first and third planting. The lowest biological yield was recorded at the last planting (5.76 $\left.\mathrm{t} \mathrm{ha}^{-1}\right)$. These differences are attributed to the effect of growth period. The results confirmed other findings [26].

TABLE IV: GROWTH DURATION, PLANT HEIGHT, AND SEED YIELD OF SUNFLOWER AS AFFECTED BY SOWING DATES IN EXTRAPOLATION AREA

\begin{tabular}{|c|c|c|c|c|}
\hline Sowing date & $\begin{array}{c}\text { Farmer } \\
(\text { No. })\end{array}$ & $\begin{array}{c}\text { Days to } \\
\text { maturity }\end{array}$ & $\begin{array}{c}\text { Plant } \\
\text { height }(\mathrm{m})\end{array}$ & $\begin{array}{c}\text { Seed yield } \\
\left(\mathrm{t} \mathrm{ha}^{-1}\right)\end{array}$ \\
\hline Dec $4^{\text {th }}$ week & 3 & 107 & 155 & 3.65 \\
\hline Jan. $1^{\text {st }}$ week & 9 & 103 & 144 & 3.31 \\
\hline Jan. $2^{\text {nd }}$ week & 6 & 101 & 147 & 2.95 \\
\hline Jan $3^{\text {rd }}$ week & 13 & 99 & 132 & 2.88 \\
\hline LSD 0.05 & - & 5 & 8 & 0.26 \\
\hline CV $(\%)$ & - & 4.7 & 5.5 & 8.3 \\
\hline
\end{tabular}

\section{E. Harvest Index}

The physiological efficiency and ability of a crop plant for converting the total dry matter in to economic yield is known as harvest index (HI). Sowing dates showed significant differences for HI. The crops planting on 14 January and 5 March had the higher HI which was at par with 29 February planting but significantly higher than 22 February planting. The HI recorded at 22 February planting was at par with 29 February planting but lower than first and last planting. The higher HI in earlier planting was influenced by accumulated intercepted radiation and grain filling duration.

\section{F. Salinity Effect}

The first planting date experienced lesser soil salinity during whole growth period compared to all other dates of planting (Table V). Up to 45 days after seeding (DAS) the soil salinity were less than 6 in case of first planting whereas it was more than 7.5 in other planting. Sunflower posses some genetic potential to grow in low to moderately salt affected areas with a thresh hold level of ECe 2.0 [27]. Seed yield has been found to start decreasing beyond ECe $2.5 \mathrm{dS}$ $\mathrm{m}^{-1}$ and reach to $30 \%$ losses at ECe $11.3 \mathrm{dS} \mathrm{m}^{-1}$ [28]. Yield losses by $49.21 \%$ were observed at EC $10 \mathrm{dS} \mathrm{m} \mathrm{m}^{-1}[29]$. However, varietal differences and environmental conditions might make plants more or less salt tolerant than the indicated value.

TABLE V: SOIL SALINITY (DSM ${ }^{-1}$ ) OF SUNFLOWER FIELDS AT DIFFERENT DAYS AFTER SOWING AS AFFECTED BY SOWING DATES

\begin{tabular}{|c|c|c|c|c|c|c|}
\hline \multirow{2}{*}{ Sowing date } & $\begin{array}{c}15 \\
\text { DAS }\end{array}$ & $\begin{array}{c}30 \\
\text { DAS }\end{array}$ & $\begin{array}{c}45 \\
\text { DAS }\end{array}$ & $\begin{array}{c}60 \\
\text { DAS }\end{array}$ & $\begin{array}{c}75 \\
\text { DAS }\end{array}$ & $\begin{array}{c}90 \\
\text { DAS }\end{array}$ \\
\hline 14 January & 4.42 & 4.64 & 5.80 & 7.70 & 7.97 & 8.58 \\
\hline 22 February & 5.98 & 6.63 & 7.57 & 8.58 & 9.17 & 9.50 \\
\hline 29 February & 6.32 & 7.12 & 7.98 & 8.67 & 9.13 & 9.62 \\
\hline 5 March & 6.72 & 7.15 & 8.03 & 8.90 & 9.50 & 9.93 \\
\hline LSD $_{0.05}$ & 0.26 & 0.33 & 0.49 & 0.50 & 0.44 & 0.28 \\
\hline CV $(\%)$ & 2.20 & 2.60 & 3.30 & 3.00 & 2.50 & 1.50 \\
\hline
\end{tabular}

\section{G. Economic Return}

The total variable cost was recorded lower in first planting of 14 January ( $\left.\$ 815 \mathrm{ha}^{-1}\right)$ compared to other planting (932 $\left.\mathrm{ha}^{-1}\right)$. The lesser TVC in earlier planting was due to planting in zero tilled fields which saved the cost of ploughing. The highest gross return of $\$ 1889 \mathrm{ha}^{-1}$ was recorded in first planting which was about 14 to $21 \%$ higher compared to other planting dates (Table VI). The higher GR in first planting was due to higher yield. The reduced TVC and higher GR from first planting resulted higher GR of \$ 1074 $\mathrm{ha}^{-1}$ which was 49 to $70 \%$ higher than those of other planting dates. Similar trend of higher GM was also recorded in earlier planting in $4^{\text {th }}$ week of December $\left(\$ 939 \mathrm{ha}^{-1}\right)$ followed by January $1^{\text {st }}$ week planting $\left(\$ 722 \mathrm{ha}^{-1}\right)$ in case of farmers' validation in the following year (Table VII). The gross margin was much lower in January second and third week planting. The higher benefit cost ratio (BCR) in 14 January planting (2.32) of sunflower proved its superiority over the other planting dates. The BCR calculated in other dates of sowing ranged 1.68 to 1.77 . The further earlier planting in 2013 , the highest BCR was recorded in December $4^{\text {th }}$ week planting (2.04) followed by January $1^{\text {st }}$ week planting (1.76). The BCR of later two weeks planting were more or less similar but lower than December $4^{\text {th }}$ week and January $1^{\text {st }}$ week sowing. The higher TVC in the extrapolation area due to application of two irrigation and increased labor wage resulted lower gross margin and BCR compared to the first year.

TABLE VI: ECONOMIC RETURN OF SUNFLOWER AS AFFECTED BY SOWING

\begin{tabular}{|c|c|c|c|c|}
\hline Sowing date & $\begin{array}{c}\text { TVC } \\
\left(\$ \mathrm{ha}^{-1}\right)\end{array}$ & $\begin{array}{c}\text { GR } \\
\left(\$ \mathrm{ha}^{-1}\right)\end{array}$ & $\begin{array}{c}\text { GM } \\
\left(\$ \mathrm{ha}^{-1}\right)\end{array}$ & BCR \\
\hline 14 January & 815 & 1889 & 1074 & 2.32 \\
\hline 22 February & 932 & 1652 & 720 & 1.77 \\
\hline 29 February & 932 & 1595 & 663 & 1.71 \\
\hline 5 March & 932 & 1564 & 632 & 1.68 \\
\hline LSD 0.05 & 0.26 & 0.33 & 0.49 & 0.50 \\
\hline CV $(\%)$ & 2.20 & 2.60 & 3.30 & 3.00 \\
\hline
\end{tabular}

TABLE VII: ECONOMIC RETURN OF SUNFLOWER AS AFFECTED BY SOWING DATES IN EXTRAPOLATION AREA

\begin{tabular}{|c|c|c|c|c|}
\hline Sowing date & $\begin{array}{c}\text { TVC } \\
\left(\$ \mathrm{ha}^{-1}\right)\end{array}$ & $\begin{array}{c}\text { GR } \\
\left(\$ \mathrm{ha}^{-1}\right)\end{array}$ & $\begin{array}{c}\text { GM } \\
\left(\$ \mathrm{ha}^{-1}\right)\end{array}$ & BCR \\
\hline Dec $4^{\text {th }}$ week & 912 & 1851 & 939 & 2.04 \\
\hline Jan. $1^{\text {st }}$ week & 955 & 1677 & 722 & 1.76 \\
\hline Jan. $2^{\text {nd }}$ week & 971 & 1498 & 527 & 1.54 \\
\hline Jan $3^{\text {rd }}$ week & 963 & 1457 & 494 & 1.51 \\
\hline
\end{tabular}

\section{CONCLUSIONS}

On the basis of the yield and economic performance, the earlier dibbling of sunflower in zero tilled fields after harvest of $T$. Aman rice could be disseminated in the coastal region. However, a further study with efficient nutrient and water management are needed to enhance the productivity of sunflower in the coastal area. Moreover, there is a need to validate the technology considering the rice-sunflower cropping system through a farmers' participatory approach. 


\section{ACKNOWLEDGMENTS}

M. H. Rashid, S. Nasrin and D. Mahalder the authors thank Mr. Tim Russell, the Chief of Party, CSISA-BD project for guiding in preparing the manuscript. Authors extended further appreciation to the community at the studied sites for their contributions to conduct the study.

\section{REFERENCES}

[1] BBS (Bangladesh Bureau of Statistics), Statistical Yearbook of Bangladesh. 2010. Statistical Division, Ministry of Planning Petersen, Dhaka, Govt. People's Repub. Bangladesh, 2010, pp.121.

[2] M. M. Rahman and M. Ahsan, "Salinity constraints and agricultural productivity in coastal saline area of Bangladesh," Soil Resources in Bangladesh: Assessment and Utilization, 2011

[3] S. A. Haque, "Salinity problems and crop production in coastal regions of Bangladesh," Pakistan J. Botany, vol. 38, no. 5, pp. 1359-1365, 2006.

[4] S. O. Agele, I. O. Maraiyesa, and I. A. Adeniji, "Effects of variety seed set efficiency in late season sunflower (Helianthus Annus L.) in a humid zone of Nigeria," Academic Journals, vol. 2, pp. 80-88, 2007.

[5] M. Nisar, S. Hussain, Nausheen, N. Khan, and M. F. Siddique, "Chemical composition of open pollinated and hybrid population of sunflower (Helianthus Annus L.)," Pakistan J. Botany, vol. 43, no. 1, pp. 157-163, 2011.

[6] E. A. Khan, S. A. Qaisrani, N. Hussain, and G. U. Sadozai, "Comparative study on the yield performance of sunflower hybrids under agro-ecological conditions of D. I. Khan," Sarhad J. Agric., vol. 28, no. 2, pp. 155-157, 2012.

[7] BBS (Bangladesh Bureau of Statistics), Statistical Year book of Bangladesh” Statistics Div., Ministry of Planning, Govt. People's Repub. Bangladesh, 2011, pp. 38.

[8] BARI, Tel Fasaler Utpadan Prajukti (Oilseed production technologies), Oil Seed Res. Centre, Bangladesh Agril. Res. Inst., Joydebpur, Gazipur, pp. 1-102, 2000.

[9] S. Rauf, "Breeding sunflower (Helianthus Annus L.) for drought tolerance," Communications in Biometry and Crop Science, vol. 3, no. 1, pp. 29-44, 2008.

[10] E. Tolga and D. Lokman, "Yield response of sunflower to water stress under Tekirdag conditions," Helia, vol. 26, no. 38, pp. 149-158, 2003.

[11] H. Turhan and I. Baser, "In vitro and In vivo water stress in sunflower (Helianthus Annuus L.)," Helia, vol. 27, no. 40, pp. 227-236, 2004.

[12] N. Katarji, J. W. Van Hoorn, A. Hamdy, and M. Mastrorilli, "Salinity effect on crop development and yield, analysis of salt tolerance according to several classification methods," Agric. Water Manag., vol. 62, pp. 37-66, 2003.

[13] F. H. Andrade, "Analysis of growth and yield of maize, sunflower and soybean grown at Balcarce, Argentina," Field Crops Res., vol. 41, pp. $1-12,1995$.

[14] A. J. De La Vega and A. J. Hall, "Effects of sowing date, genotype and their interaction on sunflower yield. I. Determinants of oil corrected grain yield," Crop Sci., vol. 42, pp. 1191-1201, 2002.

[15] S. Ahmed, F. Hassan, H. Ali, and U. Robab, "Response of sunflower to dibbling time for yield and yield components," J. Res. (Sci.), Bahauddin Zakariya University, Multan, Pakistan, vol. 16, no. 1, pp. 19-26, 2005

[16] L. A. N. Aguirrezabal, Y. Lavaud, G. A. A. Dosio, N. A. Izquierdo, F. H. Andrade, and L. M. Gonzalez, "Intercepted solar radiation during seed filling determines sunflower weight per seed and oil concentration", Crop Sci., vol. 43, pp. 152-61, 2003.

[17] Farhatullah, Farooq-E-Azam, and I. H. Khalil IH, "Path analysis of the coefficients of sunflower (Helianthus Annuus L.) hybrids," Int. J. Agri. Biol., vol. 8, no. 5, pp. 621-625, 2006.

[18] M. Arshad, M. K. Ilyas, and M. A. Khan, "Genotypic divergence and path coefficient analysis for seed yield traits in sunflower (Helianthus Annuus L.) hybrids," Pak. J. Bot., vol. 39, no. 6, pp. 2009-2015, 2007.

[19] A. Behradfar, A. H. Gorttapeh, M. R. Zardashty, and F. Talat, "Evaluation correlated traits for seed and oil yield in sunflower (Helianthus Annuus L.) through path analysis in under condition relay cropping," Res. J. Bio. Sci., vol. 4, no. 1, pp. 82-85, 2009.
[20] T. Anandhan, N. Manivannan, P. Vindhiyavarman, and P. Jeyakumar, "Correlation for oil yield in sunflower (Helianthus Annuus L.)," Elect. J. Plant Breed., vol. 1, no. 4, pp. 869-871, 2010.

[21] A. B. Yasin and S. Singh, "Correlation and path coefficient analyses in sunflower," J. Plant Breed. Crop Sci., vol. 2, no. 5, pp.29-133, 2010.

[22] F. Killi and S. G. Altunbay, "Seed yield, oil content and yield components of confection and oilseed sunflower (Helianthus Annus L.) cultivars planted in different dates," Intl. J. Agric. Biol., vol. 7, no. 1, pp. 21-24, 2005.

[23] F. Killi and O. Gencer, "The effects of sowing dates on agronomical and technological properties, and the correlations among these properties of some sunflower varieties grown under Cukurova conditions," Tr. J. Agric. Fore., vol. 16, pp. 721-729, 1992.

[24] M. P. Bange, G. L. Hammer, and K. G. Rickert, "Environmental control of potential yield of sunflower in the subtropics", Aust. J. Agric. Res., vol. 48, pp. 231-240, 1997.

[25] F. U. Hassan, R. A. Ahmad, and G. Qadir, "The influence of seasonal variations on yield and yield components of sunflower hybrids," Pertanakia J. Trop. Agric. Sci., vol. 26, no. 1, pp. 109-113, 2003.

[26] M. P. Bange, G. L. Hammer, and K. G. Rickert, "Temperature and sowing date affect the linear increase of sunflower harvest index", Agron. J., vol. 90, pp. 324-328, 1998

[27] J. K. Amacher, K. R. Koenig, and B. Kitchen, "Salinity and plant tolerance," Utah State University Cooperative Extension, AG-SO-03, 2000.

[28] M. M. Heikal, A. M. Ahmad, and A. Shaddad, "Changes in dry weight and mineral composition of some oil producing plants over a range of salinity stress," Biologia Plantarum, vol. 22, pp. 25-33, 1980.

[29] M. K. Hussain and O. U. Rehman, "Breeding sunflower for salt tolerance: genetic variability for yield and yield components for salt tolerance in sunflower (helianthus annus L.)," in Proc. All Pakistan Sci. Conf. 16-21 May, Khanspur, Pakistan, pp. 112-115, 1992.

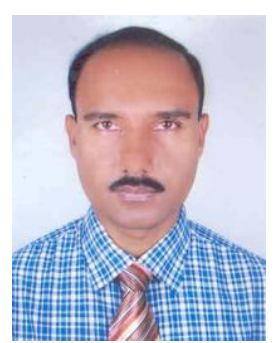

M. Harunur Rashid was born in Mymensingh, Bangladesh on August 31, 1967. Educational backgrounds of M. H. Rashid are Doctor of Philosophy in Agronomy from Bangladesh Agricultural University, Master of Science in Agriculture and Bachelor of Science in Agriculture from the same university.

Currently, he is working at the International Rice Research Institute (IRRI) as an associate scientist-cropping systems located in Khulna Bangladesh. Previously he served the Bangladesh Rice Research Institute (BRRI) as a senior scientific officer (rice-based cropping systems), National Academy for Primary Education (NAPE) as an assistant specialist, and the Department of Agronomy, Bangladesh Agricultural University as a research assistant.

His related publications are: Rashid, M. H., M. K. I. Rony, D. Mahalder, S. Nasrin. 2012. Changing Rice based farming with labor use pattern: a case from climatically vulnerable south western of Bangladesh. Proceedings of 2nd International Conference on Climate Change and Social Issues, held in Kuala Lumpur, Malaysia on 28-29 November 2012, pp. 191-205. Available at www.globalclimate.info/proceedings/; Rashid, M. H., M.K. I. Rony, S. Nasrin. 2012. Increasing productivity of rice-rice cropping system adopting short duration rice and mustard and relay cropping. In: Ganjidoust, H. and T. Yingthawornsuk Eds. 2012. International Conference Proceedings of PSRC pp. 13-16. ; Rashid, M. H., M. M. Alam, A. H. Khan, J. K. Ladha. 2009. Productivity and resource use of direct-(drum)-seeded and transplanted rice in puddled soils in rice-rice and rice-wheat ecosystems. Field Crops Research. 113(3):274-281. Research interests are resource management and simulation in rice-based cropping systems and climate change adaptation.

Dr. Rashid is the life member of Bangladesh Society of Agronomy and member of Weed Science Society of Bangladesh, Agriculturist Institution, Bangladesh Rice Research Institute Scientist Association. He was awarded for the best presentation in the International Conference on Agriculture, Environment and Humanities Engineering held on 11-12 August in Phuket, Thailand. 